\section{The recreational valuation of a natural forest park using travel cost method in Iran}

\author{
Sohrabi Saraj B ${ }^{(1)}$, Yachkaschi A ${ }^{(1)}$, Oladi $J^{(1)}$, Fard Teimouri $\mathbf{S}^{(1)}$, \\ Latifi $\mathrm{H}^{(2)}$
}

One of the most important benefits of a forest, which can be considered over the revenue yielded from timber and other wood based products, is the recreational benefits for visitors. Considering the novelty and necessity of evaluating bio-environmental economics of forest parks in developing countries such as Iran, the present study will focus on the evaluation of the Willingness to Pay (WTP) for a northern Iranian Forest park (Abbas Abad-Behshahr as a case study) utilizing one of the worldwide common methods of evaluation (Travel Cost Method). Based on the method, the park was considered as the centre of the fivefold region as concentric circles. The number of visitors was determined using questionnaires and the park's value was determined by estimation of the visitors access cost using Travel Cost Method. Furthermore, the economic value extracted timber products of the neighbouring forestry plan was reckoned. The calculated factor was then compared to the economic value of the park. As a result, the park's recreational value was judged to be much more than produced timber values. Therefore, it is concluded that the unparalleled natural, historical and bio-environmental values of the park would be preserved by planning an appropriate and well- programmed management system, considering the unique conditions of the Park. Thus, it can fulfil the recreational requirements of the people in the local/national scale.

Keywords: Recreational evaluation, Abbas Abad Forest Park, Travel Cost Method (TCM), Willingness to Pay (WTP)

\section{Introduction}

Forests feature so many values. They act as good reservoir for both wildlife and forest biodiversity among other benefits (Mugambi et al. 2006). Recreation in natural environments has been extensively increased during recent decades, following the increasing rate of the city residence process. Thus, the recreational activities now play a vital role in the public lifestyle. Therefore, equipping the natural recreational venues together with optimizing their usage has been regarded as one of the important duties of the local management.

The Iranian forest parks, located over a

(1) Dept. of forestry, Faculty of Natural Resources, University of Mazandaran, $10 \mathrm{~km}$ Sari-Neka Rd, P.O. Box 737, Sari (Iran); (2) Faculty of Forest and Environmental Studies, University of Freiburg, Freiburg (Germany)

@) Hooman Latifi (hooman.latifi@felis.unifreiburg.de)

Received: Dec 22, 2008 - Accepted: Apr 09 2009

Citation: Sohrabi Saraj B, Yachkaschi A, Oladi D, Fard Teimouri S, Latifi H, 2009. The recreational value of natural forest parks using travel cost method in Iran. iForest 2: 85-92 [online: 2009-06-10] URL:

http://www.sisef.it/iforest/show.php? id $=497$ wide range of climatic and natural conditions all across the country, are basically regarded as resources containing unique recreational potentials. The public would have different reactions to the parks since none of the regions in which the parks are located show the same condition. Moreover, people have different characteristics according to the factors such as their age, income rate, favours, etc. Ecotourism and recreation have interactive relations with several other fields like psychology, sociology, anthropology, geography, and additionally environmental economy (Oladi 2005). Nevertheless, the value and inclination of the recreational site's usage would be obtained using some worldwide evaluation methods. Regarding the other applications of the forested sites, it is of a great concern that the concept of forest recreational centres be overcome by the assumption of the land's agricultural or timber productivity or creation of other alternative land uses. Hence, evaluation of recreational sites is one of the tasks that would lead the managers to the economic value of these regions and is due to persuade them to equip the sites.

By assessment of forest parks and recreational areas which comes up to presenting the exact and accurate information and statistics, the potential land use change of the parks into other land uses can finally be avoided. Existence of several methods of evaluating the recreational values would clarify the importance of performing such a process. One method for estimating some of the non-market benefits is the Travel Cost Method (hereafter called TCM). This tool estimates ecotourism benefits of a protected area based upon observed travel expenses by visitors to the area (Mankhaus \& Lober 1996).

Various methods have been proposed so far to evaluate recreational regions and quantify the willingness to pay. The application of methods depends on the regional condition and the factors each method apply. Hotelling 1947 stated that the highest travel cost is considered to be the recreational value. Unlike the prices for private goods in efficient markets, the price of some goods, such as ecotourism, if measured only by direct costs such as entrance fees to parks, may not reflect the degree to which these goods are valued. This inaccurate pricing can result in lost revenue or underestimation of the importance of the good. One solution to this problem is to estimate visitors' willingness to pay for the good by using TCM. This model provides an estimate of the benefit individuals received from visiting a site by observing their travel-related expenses (Clawson \& Knetsch 1966, Krutilla \& Fisher 1975, Dixon \& Sherman 1991, Freeman 1993).

Clawson's study (1959) was carried out on the estimation of the relationship between the visitors and their residential area's distance from the park. Nowadays, this method is one of the most common ways of evaluating the recreational values, well-known as the TCM, which has been widely used for valuing nature-based recreation (Brown \& Mendelsohn 1984, Caulkins et al. 1986, Bell \& Leeworthy 1990, Fletcher et al. 1990, Englin \& Mendelsohn 1991, Willis 1991, Garrod \& Willis 1992, Adamovicz 1994, Adamowicz et al. 1994, Offenbach \& Goodwin 1994, Mankhaus \& Lober 1996, Mugambi et al. 2006, Shrestha et al. 2007).

Hanley (1989) used the TCM and Contingent Valuation Method (CVM - a method based on creating a virtual market to evaluate non-market goods and services) in the Queen Elizabeth Park (Scotland). The study showed that the Willingness to Pay (WTP) in TCM is less than the one obtained of CVM. However, he didn't identify which one is more acceptable. Fix \& Loomis (1998) applied TCM and CVM for evaluation of nonmarket facilities in the American Biking Mountains as the study area. They consequently calculated 235 and 206 USD for each hectare by the use of CVM and TCM, respectively. The results clarified that the amount of WTP has been shown slightly 


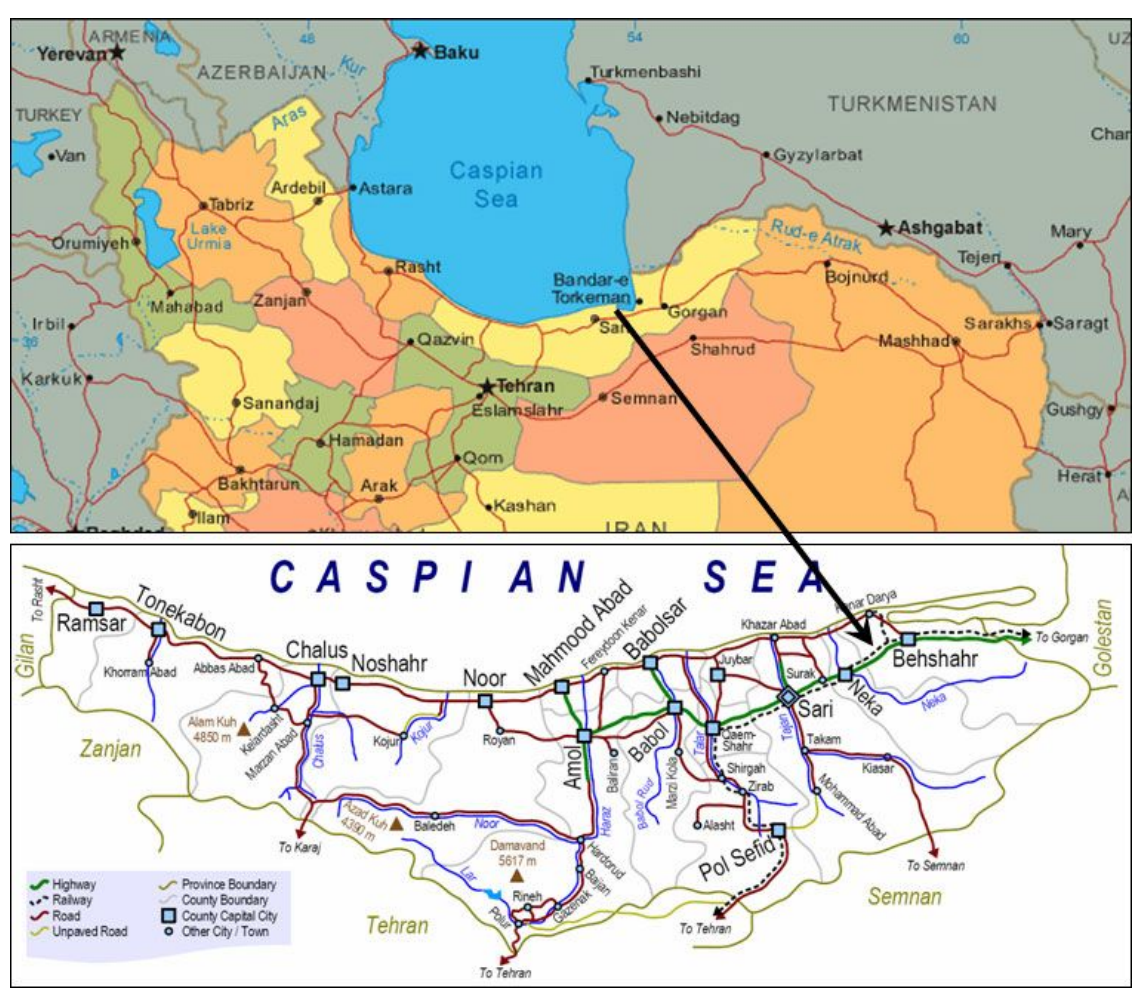

more in CVM, compared to TCM.

Rosenberger (1999) carried out a research in recreational regions of Rocky Mountains (USA) utilizing a set of empirical studies amongst various methods including CVM (where some structural questions would be used for the evaluation), Hedonic Pricing Method (HPM - evaluation of goods, services or non-marketable services based on a virtual market), and TCM. An extended combination was obtained during the study and recreational travels were taken into account as "the real travels for the first time". It also stated natural sources as "the most important factor for tourist attraction".

However, some studies such as Hanley et al. (1998) reported that methods like Choice experiments have important advantages over other environmental valuation methods, such as CVM and TCM. In addition to this, Common et al. (1999) remark that TCM is not able to evaluate the entire economic value of a region. Nevertheless, it is the best method to study the changes in WTP in a recreational site.

In Iran, Yachkaschi (1975) carried out an evaluation process of recreational sites for the first time. He evaluated Si-Sangan forest Park (located in central Mazandaran, northern Iran) using TCM, applying some evaluation methods. The study led to some suggestions for further extension the forest park. Majnounian (1977) calculated the rate of 369,000 Rials (about 434 USD) as the recreational value of Tehran forest Park (in case of having an additional entrance fee of $5 \mathrm{Ri}$ als), based on the former study. Arbab
(2003), however, suggested that CVM should not be used in developing countries. According to Cooper (2000), TCM is "the best method of evaluating and determining WTP of recreational regions". TCM has been widely proposed for evaluating nonmarket goods and/or services. It has been especially used for evaluating recreational sites in Iran. Hence, the main objective of this study was to use TCM to empirically estimate the value of ecotourism benefits of $\mathrm{Ab}$ bas Abad forest park, as one of the most potentially - hedonic forest parks across the region.

\section{Materials and Methods}

\section{Study area}

The study site is Abbas Abad, a 138 ha forest park located near Behshahr town in Mazandaran Province, northern Iran ( $36^{\circ} 39^{\prime}$ $50^{\prime \prime}$ to $36^{\circ} 47^{\prime} 32^{\prime \prime} \mathrm{N}$ and $53^{\circ} 36^{\prime} 00^{\prime \prime}$ to $53^{\circ}$ $42^{\prime} 40^{\prime \prime}$ E - Fig. 1). The temperature averages $15.6{ }^{\circ} \mathrm{C}$, the annual precipitation is over $640 \mathrm{~mm}$, and the average altitude is 450 to $530 \mathrm{~m}$ above sea level.

Abbas Abad forest Park is one of the Mazandaran's most significant recreational places which have been a temporal host for numerous visitors coming from all over the country. The area's importance is mainly because of its special historical and natural situation. The park, in which a set of wonderful natural and artificial landscapes including a historical dam and a ruin bathroom (belonging to the first King Abbas of Safavid's dynasty) exist, is situated origi-
Fig. 1 - Location of the study area.

nally in a portion of old-growth northern forests of Iran, composed mainly of broadleaf species such as Fagus orientalis Lipsky., Carpinus betulus L., Quercus castaneifolia C.A. Mey., Parrotia persica C.A. Mey., and some more. The forests have always been considered as a recreational place for the civilians who aim to use the natural features of such venues in the best way. It is remarkable that Abbas Abad management plan has been introduced as one of 10 superior Recreational plans by the Cultural Heritage and Recreation organization of Mazandaran Province (Iran). In the near future, probable development and equipment of the park might lead it to become one of the most important recreational centres in the region.

\section{Methods}

There are a number of techniques developed by economists which can be used to assess the economic benefits generated by wilderness recreation. Two prominent methods are the travel cost method (TCM) and the Contingent Valuation Method (CVM).

TCM, as stated above, has undergone slight modifications from 1947 so far, and has been completed more. This method had already been called "Clawson's Method", but it is now well known as "TCM" worldwide. The travel cost method is used to estimate the value of recreational benefits generated by ecosystems. It assumes that the value of the site or its recreational services is reflected in how much people are willing to pay to get there. It is referred to as a "revealed prefe- 
Fig. 2 - Schematic design of TCM.

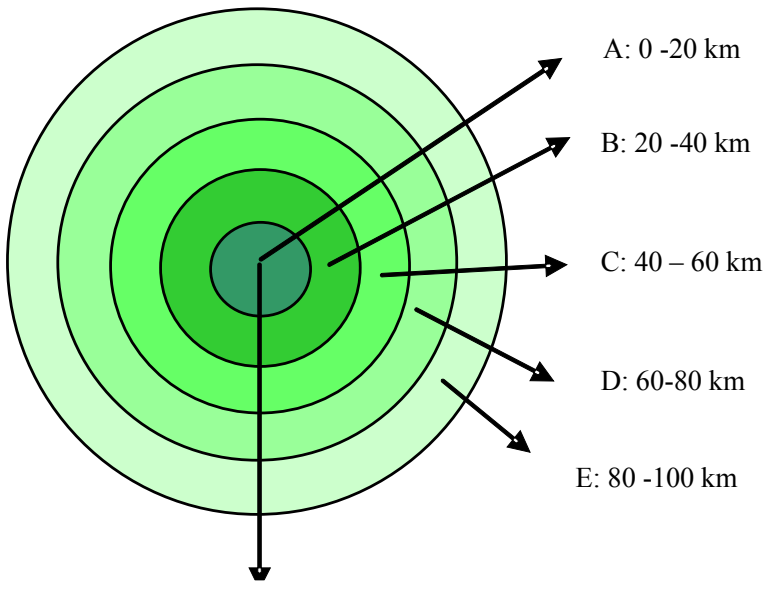

Abbas Abad Forest Park

rence" method, because it uses actual behaviour and choices to infer values. Thus, peoples' preferences are revealed by their choices.

Two variations of the TCM include:

- Simple Zonal TCM, using mostly secondary data, with some simple data collected from visitors.

- Individual TCM, using a more detailed survey of visitors.

The zonal travel cost method is the simplest and least expensive approach. It will estimate the value for recreational services of the site as a whole. It cannot easily be used to value a change in quality of recreation for a site, and may not consider some of the factors that may be important determinants of value.

The zonal travel cost method is applied by collecting information on the number of visits to the site from different distances. Because the travel and time costs will increase with distance, this information allows the researcher to calculate the number of visits "purchased" at different "prices." This information is used to construct the demand function for the site, and estimate the consumer surplus, or economic benefits, for the recreational services of the site.

The individual travel cost approach is similar to the zonal approach, but uses survey data from individual visitors in the statistical analysis, rather than data from each zone This method thus requires more data collection and slightly more complicated analysis, but will give more precise results.

The method selected for data analysis here was a zonal TCM, which was chosen because of two main reasons. First, the existing data included all information needed for estimation of a zonal TCM, whereas the information for other valuation methods would have necessitated an expensive survey. Second, the available CHRO (the Cultural Heritage and Recreation Organization) data base does not include observation on indi- vidual or household income.

TCM has straightforward basic principles in which the park (study site) is chosen as the centre of concentric circles (Fig. 2). Then, by the use of questionnaires, it would be clarified that how many people has visited the park during a specific period. During the study, people were asked to fill the questionnaires only if they visited the park for leisure and with a recreational intention. Using this method, five regions were determined and named as A, B, C, D, and E. The regions had the radius of $20,40,60,80$, and $100 \mathrm{~km}$ from the park centre, respectively. The area of each region was calculated formerly using the dot grid method at $95 \%$ accuracy (Zobeiri 2000).

WTP is a portion of the income rate which the consumer is due to pay to improve the welfare condition or prevent its decline. WTP is used to demonstrate the natural resource's total value for which the consumer will pay to visit. Thus, WTP was calculated using the following formula (eqn. 1):

$$
W T P=\sum_{i=1}^{n} n_{i} \int_{p_{i}}^{p} Z(p) \cdot d p
$$

where $\mathrm{Z}(\mathrm{p})$ is functions of visitors' ratio $(\mathrm{z})$ subtract the whole visitors divided by the whole population; $\mathrm{P}$ is the travel cost average; $\mathrm{N}$ is the different regions of main recreational site; $n_{i}$ is the population of the region I; $\mathrm{p}_{\mathrm{i}}$ is the travel cost average of each visitor in region $i$ which rate could be decreased down to zero.

The formula has also been used to evaluate the increase or decrease of the resource value resulted from environmental quality change across the area (Arbab 2003). The available population census (prepared in 1996 by the National Statistical Centre) was used to calculate the number of people residing inside the zones. The number of the dwellers of the five zones who visited the forest Park was calculated. Besides, the visitors who had no previous decision to visit the park were excluded in the calculation of the park visitors.

The travel cost is equal to the car depreciation rate, in addition to the consumed petrol price per $\mathrm{km}$. The entire value of the Abbas Abad Park region was gained as the sum of the calculated costs belonging to the five regions.

\section{Results}

\section{Characteristics of visitors}

Most visitors who filled the questionnaires were male, married, and 21 to 30 years old. They averagely had a high school diploma degree, non-governmental careers, and average monthly income around $1,200,000$ to $2,000,000$ Rials ( $\approx 140$ to 200 USD).

\section{The Number of the visitors}

Some of the socio-economic characteristics of visitors are summarized in Fig. 3.

According to the results obtained from the study, $14 \%$ of the visitors have visited the park without any previous recreational intention and thus have been eliminated from the calculations. It was formerly specified that almost 908 people have visited the park during the work days and 2146 during the weekend. Providing that totally 294 work days and 72 holidays existed in the period between Summer 2004 to the end of spring 2005 , the number of visitors of the Park has been around 422,000. According to the total estimated area of the Abbas Abad recreational site (nearly $138 \mathrm{ha}$ ), the amount of visitors $\mathrm{ha}^{-1} \mathrm{yr}^{-1}$ was equal to 3057 . Realistically speaking, only 13 ha of the entire 138 ha would be intensively used by the visitors; hence, the amount would be equal to 32,400 people $\mathrm{ha}^{-1} \mathrm{yr}^{-1}$. As it may be realized, the number of visitors per ha is superfluous, which can probably lead to cause potential ecological harms to the site. Yachkaschi (1975) proved that exploiting the capacities of recreational sites have led gradually to plant biodiversity decline and soil compaction in Si-Sangan forest Park. The signals of such a phenomenon have been also seen in the present study area. As a result, it seems that proper distribution of the recreational equipment across the park can decrease the rate of ecological pressure per ha, which makes more visitors able to be hosted in a

Tab. 1 - The number of visitors per region.

\begin{tabular}{ccc}
\hline Region & $\begin{array}{c}\text { Number of } \\
\text { visitors }(\times \mathbf{1 0 0 0 0})\end{array}$ & $\begin{array}{c}\text { Percent of } \\
\text { visitors }\end{array}$ \\
\hline A & 21 & 49 \\
B & 8.5 & 20 \\
C & 7.6 & 19 \\
D & 3 & 7 \\
E & 2.1 & 5 \\
Total & 42.2 & 100 \\
\hline
\end{tabular}



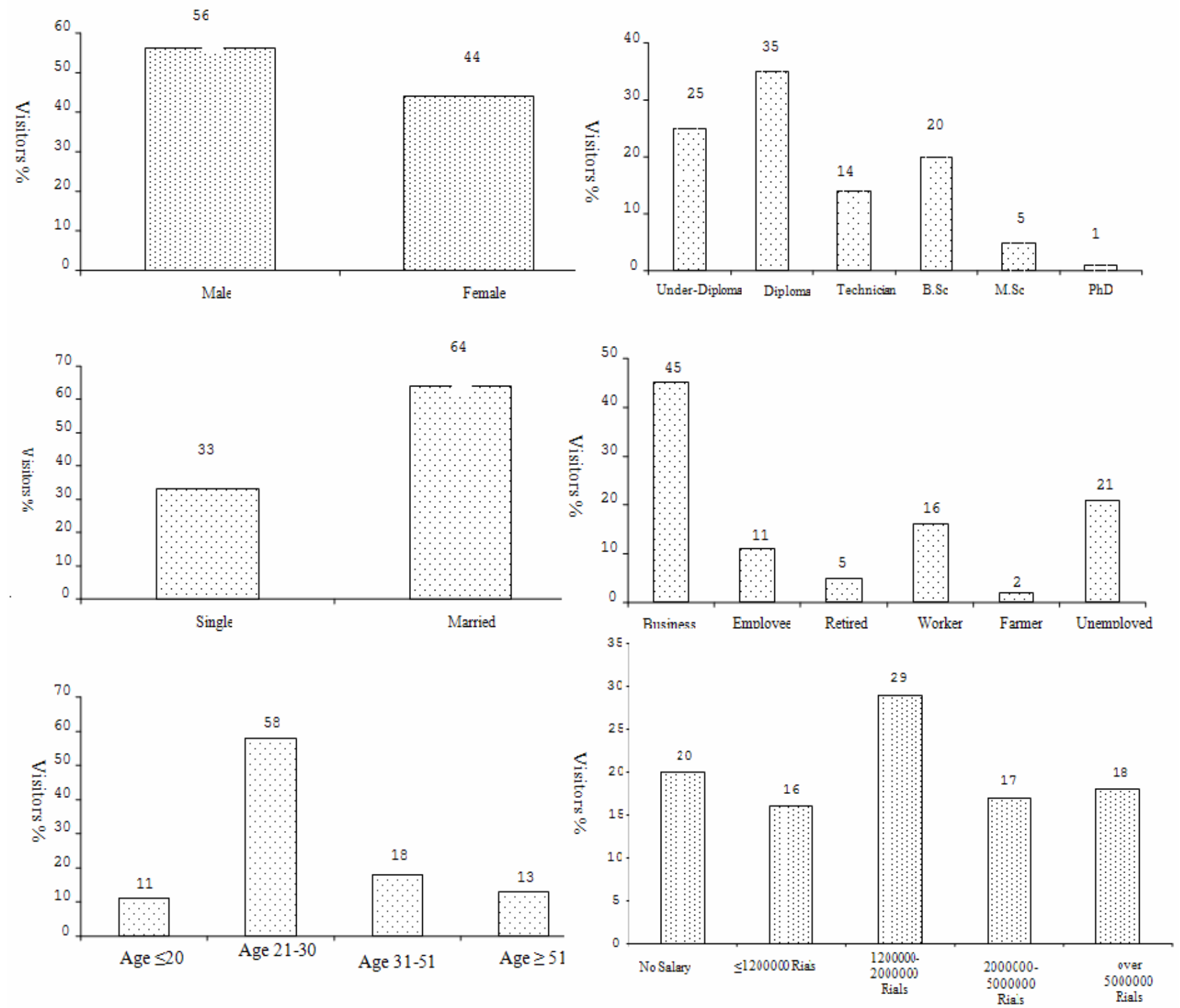

Fig. 3 - Some socio-economic characteristics of the Abbas Abad Park visitors. Left (from top to bottom): Gender, Marriage status, and Age of visitors. Right (from top to bottom): Educational level, main Carrier categories, and Level of income.

wider space.

\section{The number of incoming vehicles}

Some $96 \%$ of the visitors has visited the park using motorized vehicles, mostly (around 65\%) using their own private vehicles. Generally speaking, a number of 143,200 vehicles have entered the park, which included 312 vehicles during the working days and 715 during holidays.

\section{The amount of visitors and distance}

The relation between the number of visitors and their distance to the park is reported in Tab. 1. Results illustrated in the table show how many people have visited the park from the pre-determined zones. Almost $95 \%$ of visitors inhabit at most $100 \mathrm{~km}$ far of the park. Also, people living in region "A" are the major portion of the visitors, residing less than $20 \mathrm{~km}$ distant from the park. In contrast, the "E" region's population form the minimum portion the visitors. The decreasing relation between distance and visitors' rate showed a relatively high correlation coefficient (Fig. 4).

\section{Determining the Cost value}

In order to determine the park's cost value, the visitor's car depreciation cost should be taken into account, in addition to the petrol price. Paykan (as one of the main available family cars used widely across the country) petrol consumption is 12 litres per $100 \mathrm{~km}$ on average. Assuming that the petrol price was fixed at 800 Rials per litre in 2004-2006 $(\approx 0.1$ USD), each car's petrol price would be 9600 Rials (1.2 USD). If petrol and depreciation cost per km would be 224.5 Rials, the mentioned price for an average of 3 people (averagely carried by each vehicle) would be 75 Rials ( $\approx 0.08$ USD).

The formulas considering one time visit cost, monetary park value, and final park value are as follows (eqn. 2-4):

$$
\begin{gathered}
O T V C=T C K M \cdot A T W D \\
M P V=O T C V \cdot T V \\
F P V=M P V \cdot N R
\end{gathered}
$$

where OTVC is the one time visit cost; TCKM is the travel cost per km; ATWD is the average two-way travel distance from the visitor's home area; MPV is the Monetary 


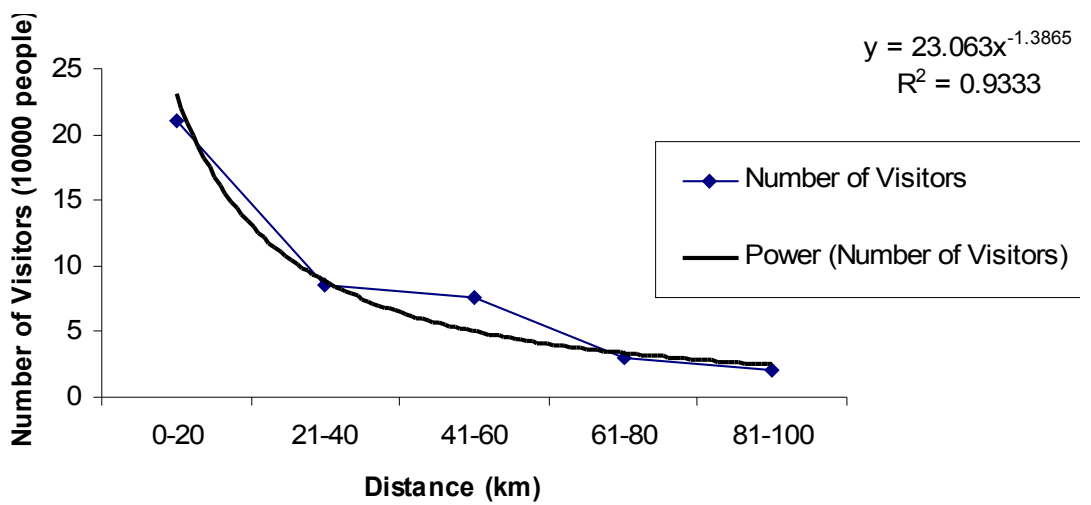

Fig. 4 - Relation between distance and the number of visitors.
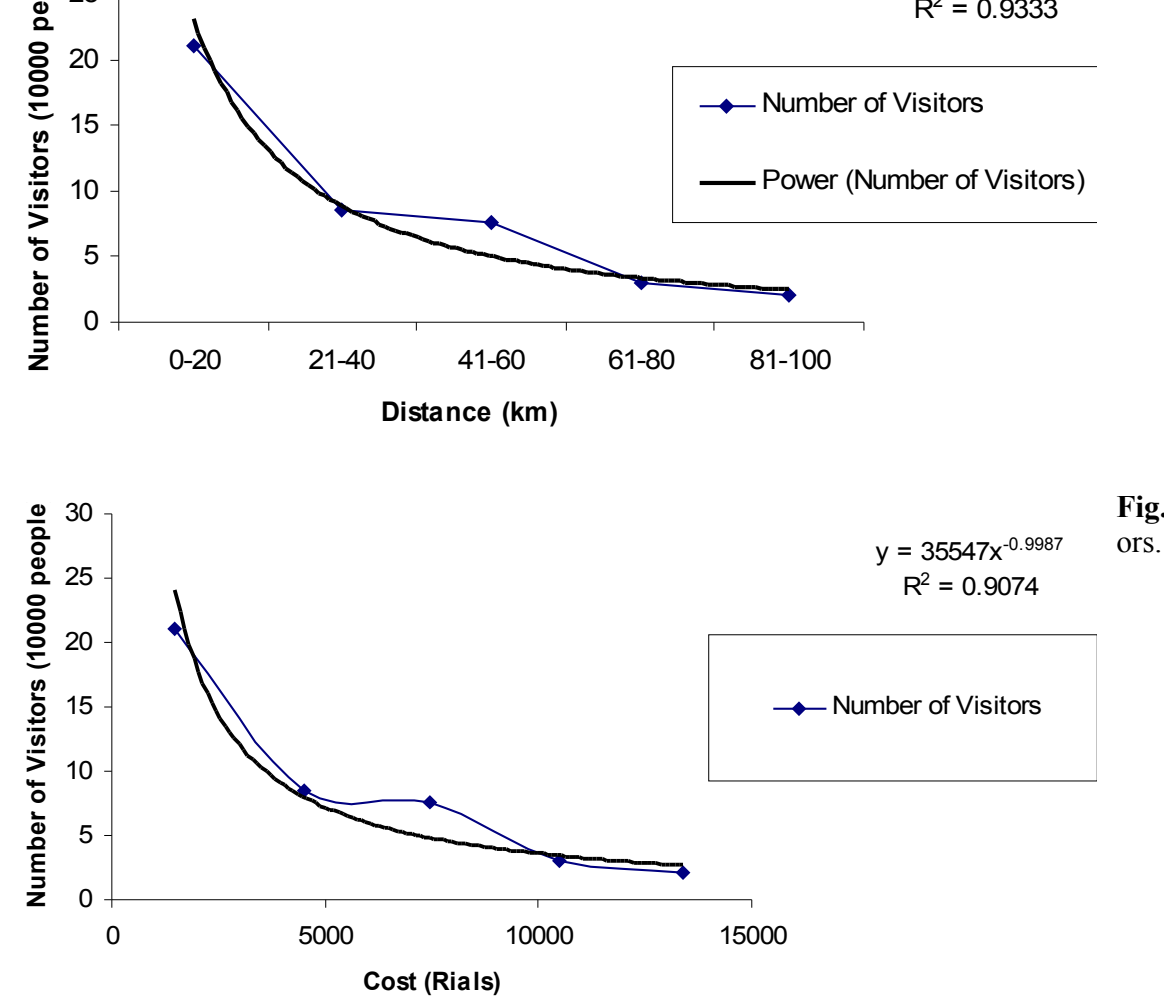

Fig. 5 - Relation between cost and amount of visitors.
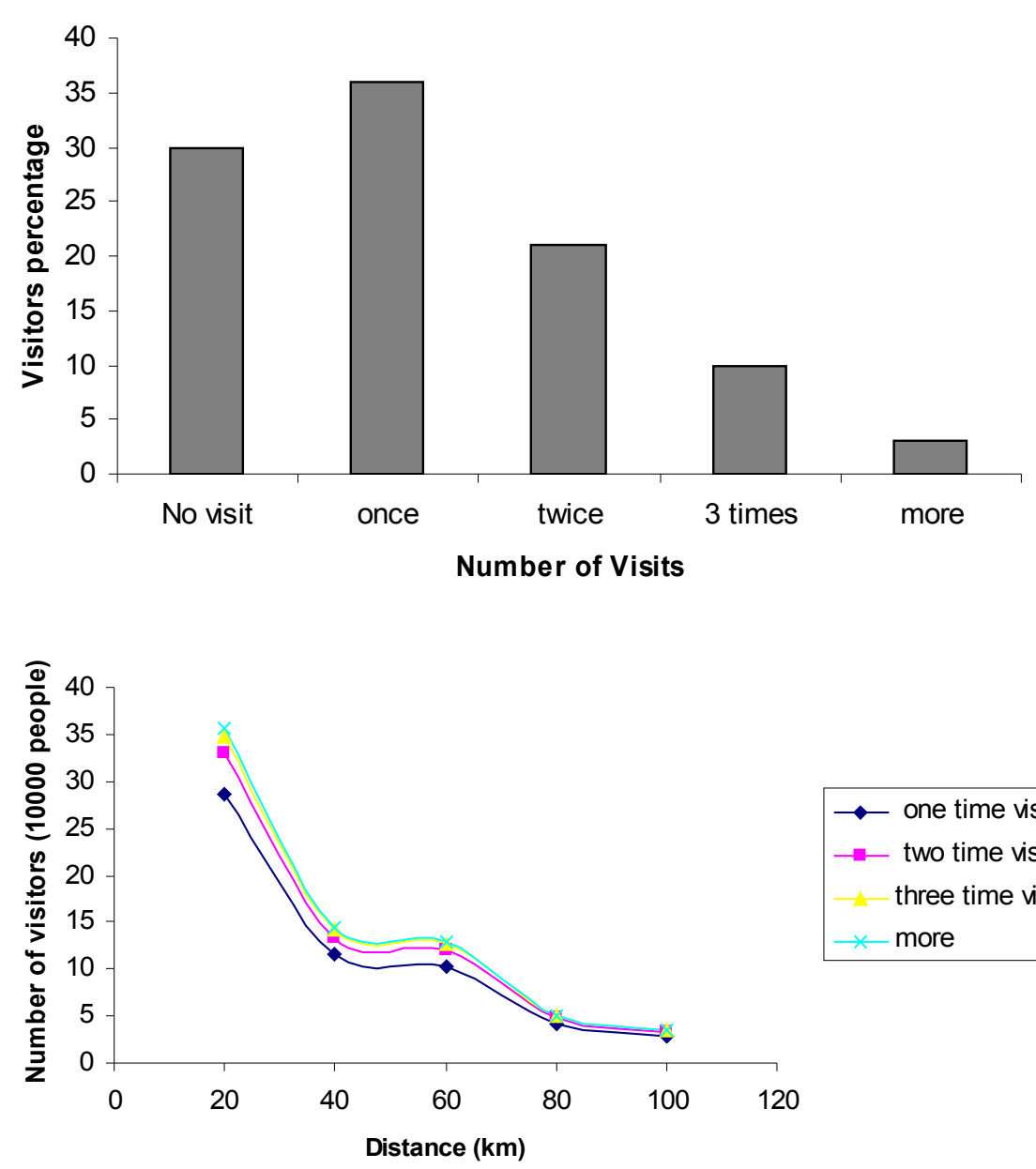

Fig. 6 - The amount of the park visits in case of availability of public transportation facilities.

Fig. 7 - Increase of WTP in case of availability in public vehicles. 
Tab. 2 - Produced timber value of Abbas Abad-Khalil mahalleh Forestry Plan.

\begin{tabular}{|c|c|c|c|c|c|c|c|c|}
\hline Species & $\begin{array}{c}\text { Mixture } \\
\text { portion \% }\end{array}$ & $\begin{array}{l}\text { Industrial } \\
\text { Timber \% }\end{array}$ & $\begin{array}{c}\text { Fuel } \\
\text { wood \% }\end{array}$ & $\begin{array}{c}\text { Industrial } \\
\text { Timber }\left(\mathbf{m}^{3}\right)\end{array}$ & $\begin{array}{c}\text { Fuel } \\
\operatorname{wood}\left(\mathbf{m}^{3}\right)\end{array}$ & $\begin{array}{c}\text { Industrial } \\
\text { Timber } \\
\text { gained profit } \\
\text { (Rials) }\end{array}$ & $\begin{array}{l}\text { Fuel wood } \\
\text { gained Profit } \\
\text { (Rials) }\end{array}$ & $\begin{array}{c}\text { Total value } \times \\
\text { Mixture } \\
\text { portion }\end{array}$ \\
\hline Carpinus betulus & 60 & 41 & 59 & 1 & 1.5 & 300000 & 52500 & 211000 \\
\hline Parrotia persica & 20 & 14 & 86 & 0.35 & 2.15 & 76000 & 75250 & 30000 \\
\hline Fagus orientalis & 10 & 49 & 51 & 1.22 & 1.28 & 717000 & 44800 & 76000 \\
\hline Other species & 10 & 37 & 63 & 0.9 & 1.6 & 189000 & 56000 & 24000 \\
\hline Total & 100 & - & - & - & - & - & - & 341000 \\
\hline
\end{tabular}

Park value; TV is the total number of incoming visitors from the region; FPV is the Final Park value; NR is the number of regions.

The populations from $\mathrm{A}, \mathrm{B}$ and $\mathrm{C}$ regions (up to $60 \mathrm{~km}$ distance from the park) form the bulk of visitors, as the others visit the park occasionally passing the region. So, the cost value of the park may be calculated based on these three zone's users. The value would be then 1,266 million Rials for the entire recreational site (138 ha), 9 million per ha, and 97 million for one hectare of the central 13 ha within the site. The relation between costs and the number of visitors, showing a correlation of 0.9 , is depicted in Fig. 5.

As expected, the larger is the cost, the lower is the number of visitors coming from fivefold regions.

\section{Determining the cost value of timber production}

Khalil Mahalleh-Abbas Abad forestry plan (located in north eastern neighbourhood of the Park) has been selected for the assessment of the timber production cost value. The percentage of tree species types, industrial timber and fuel woods were specified independently to determine the cost value. Finally, the pure profit for industrial timber was set to $30 \%$ of the average market price and $10 \%$ of the fuel wood's market price (according to the information of the forestry

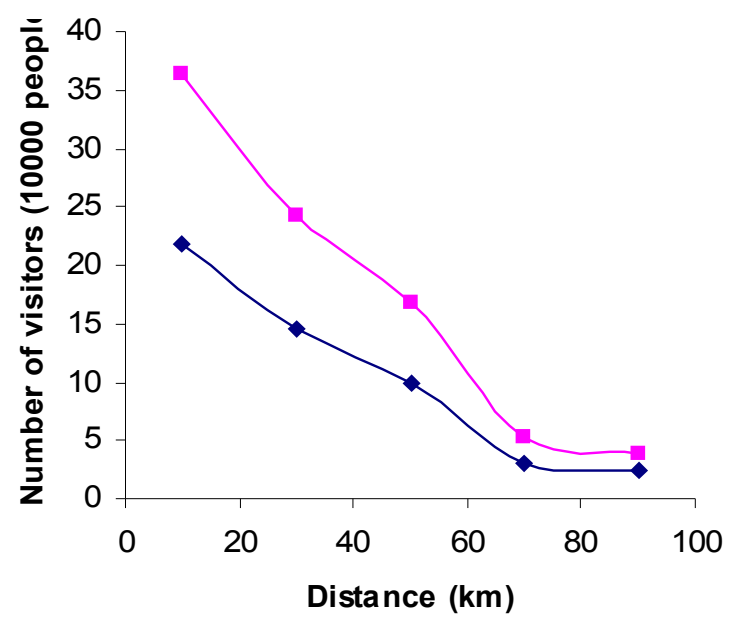

plan - Tab. 2). As a consequence, the recreational value of the park per ha was gained, which was equal to 341,000 Rials (on average 40 USD).

\section{Increasing WTP in case of availability of public vehicles}

To achieve the WTP diagram, the following question has been posed: "How many times you would visit the park providing that enough two-way public transportation facilities would be available?". Some $30 \%$ asserted that they prefer to travel by personal vehicles, while $2 / 3$ stated that they are interested in travelling by public vehicles, provided the price is reasonable. The frequency of the park visits is depicted in Fig. 6 . The visiting trend of the park would raise upwards and rightwards, as reported in Fig. 7.

The raise in the number of visitors for "entire area", "138 ha study site" and "central 13 ha" would be equal to 717000,5000 and 5500 people per ha respectively. In addition, the cost value of the park will reach 2152, 15 and 165 million Rials $(253000,1764$, and 19400 USD) per ha, respectively.

\section{The increase of WTP in case of creating residential places}

In order to study the issue, visitors were requested to answer to the following question through the planned questionnaire: "Are you interested in staying in the park over night, if suitable equipments (e.g., tent and/or camping facilities) would be available?". Some $67 \%$ of the respondents answered yes. The diagram drawn after the analysis shows an increasing trend upwards and rightwards (just as the case of public vehicles availability - Fig. 8).

According to the corresponding figure, the amount of visitors would increase as following in case of residential service improvement: some 675,000 people in the entire general area, 4,800 in the 138 hectare study site, and 51,900 in the central 13 hectares. The cost value would thus be 2025,14 , and 155 million Rials (equivalent to 238,000 , 1,600 , and 18,200 USD) in the entire area, in the 138 hectares study site, and in the inner 13 hectares, respectively.

\section{The decrease in WTP in case of entrance} fee determination

There are a number of effective factors which may cause the visitors to limit (or even give up) their use of the park. Increasing the travel costs, the decline of ecotourism services, and/or decreasing the quality of eco-environmental resources are considered amongst the possible reasons which would cause the decrease in WTP of the park user.

In this study, it was attempted to investigate the tendency of WTP, as a consequence of setting different entrance fees for the five

Fig. 8 - Increasing the WTP if residential facilities would exist.

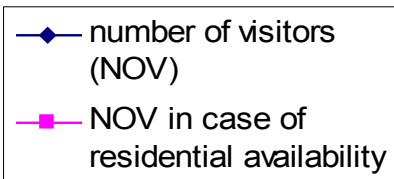




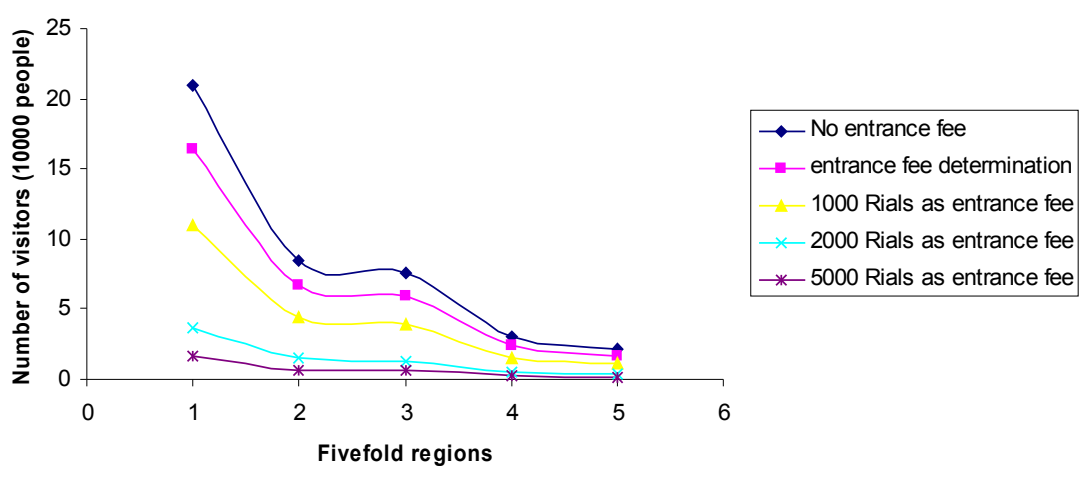

Tab. 3 - Decrease of WTP in case of entrance fee determination.

\begin{tabular}{cccc}
\hline \multirow{2}{*}{$\begin{array}{c}\text { Conducted } \\
\text { Entrance fee }\end{array}$} & $\begin{array}{c}\text { Number of Visitors } \\
(\mathbf{x} 1000)\end{array}$ & \multicolumn{2}{c}{$\begin{array}{c}\text { Value per ha } \\
\mathbf{( 1 0 0 0} \text { Rials) }\end{array}$} \\
\cline { 3 - 4 } & & In the inner 13 ha & In 138 ha study site \\
\hline No fee & 32.9 & 169300 & 15950 \\
1000 Rials & 22 & 113400 & 10600 \\
2000 Rials & 6.5 & 37250 & 3500 \\
5000 Rials & 4.4 & 17100 & 1600 \\
\hline
\end{tabular}

provenance regions. First, people were asked for their willingness to pay an entrance fee to visit the park. If yes, how much would they accept to disburse?

The responses to the above question was up to 1000, 2000, and 5000 Rials (around $1.1,2.3,5.8$ USD) as for the entrance fee. Hence, it is obvious that fewer visitors would potentially travel to the park from the five provenance region, if an entrance fee would be set, determining a reduction of the cost value of the park. As displayed in Fig. $9,77 \%$ of the visitors would accept to pay the entrance fee, of which $66 \%$ was willing to pay up to 1000 Rials, $19 \%$ up to $2000 \mathrm{Ri}$ als, and $15 \%$ up to 5000 Rials to enter the park.

As a consequence of setting an entrance fee (supposed that no improvement would be done in the recreational condition), the cost value of Abbas Abad Park would be decreased down to 974,000,000 Rials (almost 114,588 USD) in the total area, 7,000,000 Rials (around 823 USD) in 138 hectares and $74,000,000$ Rials (about 8,705 USD) in the inner 13 hectares of the park (Tab. 3 and Fig. 9).

\section{Discussion}

Nature-based recreation and tourism is touted as a sustainable means to preserve natural resources while providing a diversity of economic benefits to local communities and national economies (Gossling 1999, Wunder 2000, Wood 2002). Usually, many factors affect the economic issues, each having a special degree of importance. Other affecting conditions should be typically considered constant when investigating a specific variable's effects. In the curve related to a recreational site's demand, so many visitors' reactions would be thus ignored to specify the relation between the cost and the amount of uses. The cost doses not solely specify the user's behaviour, but it is surely the most effective factor. Clawson (1959), Yachkaschi (1975), Cooper (2000), Kavianpour \& Esmaeili (2002) have already studied this topics, observing a direct relation between the cost and the number of visitors. The relation also holds true for Abbas Abad forest park.

The results of the present study showed that improving the eco-environmental sources and/or ecotourism services can have a valuable effect on the increase of the visitor's demands and the WTP in such a forest park, though other effective factors like costs, users characteristics, distance to access the park, time needed to reach the park, time needed to pass through the area, people's leisure time, amount of working hours per week, the visitor's job, the population residing in the park's region, available installations and facilities, and the landscape features actually act a role in the demand. $\mathrm{Ne}$ vertheless, the improvement of eco-environmental resources/services can be the most significant factor which could be effective in visiting the park, in addition to the costs and users income. Accessibility of enough public transportation facilities (e.g., tele-cabin, hostels/residential venues offering required facilities) can persuade many more visitors to visit the area. This would furthermore be beneficial in improving the economic condition of the local people (residing in Behshahr and surrounding areas) as Oladi (2005) stated that main aim of the recreation is preserving natural sources and creating income sources for local societies.
Fig. 9 - Decreasing WTP in the case of enacting entrance fee.

\section{Conclusion}

According to the achieved results, the recreational value of the Abbas Abad (1266 million Rials for the entire recreational site 138 ha -, 9 million per ha, and 97 million per hectare for the central 13 ha area within the site) is much higher if compared to timber production value $(341,000$ Rials per ha, on average 40 USD). In other words, the timber value is just $4 \%$ of the total park value. Therefore, activities should be carried out in order to preserve, expand, and equip the site for recreation. This would be rewarding also to the local management units and related organizations (e.g., forest, rangeland, and watershed organization of I.R. Iran) which would improve their economic condition, together with supporting the economical conditions of local people. The Abbas Abad Park management should thus be enriched by conducting chain work plans, optimizing eco-tourism services and removing factors discouraging Park visits.

Some suggestions may be eventually recommended as follows:

- Training the eco-environmental issues inside the forest Park can be done applying different tools and equipments to improve the eco-environmental culture of the visiting people.

- Eco-environmental evaluation using the worldwide-accepted methods can be done for other Iranian forest parks to prevent their further demolition and limitation.

- Interested institutions (e.g., Agriculture and Natural Resources Research Institute of Mazandaran Province) are supposed to act more efficiently on promoting this recreational/ecologically unique region.

- Interested organizations (those involved in preserving and improving forest parks) could create forest parks in other suitable areas across the province to reduce the tourist pressure on the Abbas Abad Park.

- WTP of other ecotourism facilities can be calculated by the use of TCM.

- Factors involved in increasing/decreasing WTP in the Park may be recognized andapplied/avoided to improve and optimize the park performance (e.g., vehicles access into the park should be restricted to certain limits to prevent acoustic pollution, or res- 
taurants and dining facilities should be prevented to be gathered just in a certain part of the park because of possible ecological troubles they can cause).

- The expansion and improvement of the park is strongly recommended by creating ecotourism equipments.

- According to the official definition of a forest park (expanding and equipping the park up to $60 \%$ of its area), it is proposed to expand the park's area up to 83 hectares, together with installing the necessary facilities based on the visitors' requirements. These can include installing rubbish buckets, tables and benches, pavements, health service, traditional tea shops, children's specific areas, optimizing the use of Abbas Abad dam, establishing theatre halls, cinema, suitable sport fields, and other welfare activities to make the park more pleasant for the visitors. Such a statement has also been emphasized by Shrestha et al. (2007), who stated that "managers can enhance the value of nature-based recreation in the Apalachicola River region if they increase the opportunities for visitors to experience more pristine recreation areas".

- Setting an entrance fee to access the Park at 2000 Rials (almost 2.3 USD) and doubling it for each entering car (this fee has been formerly received by the management only in summer time). According to the available statistics of 2004 and 2005, a number of 143,200 cars visited the park. Assuming a costant trend for the year 2006, 572,800,000 Rials (nearly 67,300 USD) would be gained by the management. Provided that this money could be spent for expanding and equipping the park, this would consequently affect and improve the socio-economical condition of the local people as well.

The results of this study provide useful information for natural resources management in the region and a rationale to preserve a part of the Northern Iran's unique forest ecosystems.

\section{References}

Adamowicz W (1994). Habit formation and variety seeking in a discrete choice model of recreation demand. Journal of Agricultural and Resource Economics 19 (1): 19-31.

Adamowicz W, Louviere J, Williams M (1994). Combining revealed and stated preference methods for valuing environmental amenities. Journal of Environmental Economics and Management 26: 271-292. - doi: 10.1006/jeem.1994.1017

Arbab H (2003). Environmental and natural resources economics. Nei Publications, pp.73.

Bell FW, Leeworthy VR (1990). Recreational demand by tourists for saltwater beach days. Journal of Environmental Economics and Management
18 (3): 189-205. - doi: 10.1016/00950696(90)90001-F

Brown G, Mendelsohn R (1984). The hedonic travel cost method. The Review of Economics and Statistics 66: 427-433. - doi: 10.2307/1924998

Caulkins P, Bishop RC, Bouwes NW (1986). The travel cost model for lake recreation: a comparison of two methods for incorporating site quality and substitution effects. American Agriculture Economics Association, pp. 291-297.

Clawson M (1959). Methods of measuring the demand for and value of outdoor recreation. Resources for the future, Reprint Number 10 , Brookings Institutions, Washington, DC, USA.

Clawson M, Knetsch JL (1966). Economics of outdoor recreation. The Johns Hopkins Press, Baltimore, ML, USA.

Common M, Sen A, Selden T (1999). The travel cost method. Australian journal of Agricultural and Resource Economics 43 (4): 457-477. - doi: 10.1111/1467-8489.00090

Cooper JC (2000). Nonparametric and semi-nonparametric recreational demand analysis. American Journal of Agricultural Economics 82 (2): 451-462.

Dixon JA, Sherman PB (1991). Economics of protected areas. Ambio 20: 68-74. [online] URL: http://www.jstor.org/pss/4313779

Englin J, Mendelsohn R (1991). A hedonic travel cost analysis for valuation of multiple components of site quality: the recreation value of forest management. Journal of Environmental Economics and Management 21 (3): 275-290. - doi: 10.1016/0095-0696(91)90031-D

Fix P, Loomis J (1998). Comparing the economic value of mountain biking estimated using revealed. Journal of Environmental Planning and Management 41 (2): 227-236. - doi: 10.1080/09640569811731

Fletcher JJ, Adamowicz W, Graham-Tomasi T (1990). The travel cost model of recreation demand: theoretical and empirical issues. Leisure Sciences 12: 119-147.

Freeman AM (1993). The measurement of environmental and resource values: theory and methods. Resources for the future, Washington, DC, USA.

Garrod G, Willis K (1992). The amenity value of woodland in Great Britain: a comparison of economic estimates. Environmental and Resource Economics 2 (4): 415-434. - doi: 10.1007/BF00304970

Gossling S (1999). Ecotourism: a means to safeguard biodiversity and ecosystem functions. Ecological Economics 29: 303-320. - doi: 10.1016/S0921-8009(99)00012-9

Hanley N (1989). Valuing rural recreatin benefits. Journal of Agricultural Economics 40 (3): 361374. - doi: 10.1111/j.1477-9552.1989.tb01117.x Hanley N, Wright RE, Adamovicz V (1998). Using choice experiments to value the environment. Environmental and Resource Economics 11 (34): 413-428. - doi: 10.1023/A:1008287310583
Hotelling H (1947). The economics of exhaustible resources. Journal of Political Economy 39: 137. 175. - doi: 10.1086/254195

Kavianpour K, Esmaeili A (2002). Recreationaleconomical evaluation of Si Sangan forest park. Pajouhesh and Sazandegi 55: 92-95.

Krutilla JV, Fisher AC (1975). The economics of natural environments: studies in valuation of commodity and amenity resources. The Johns Hopkins University Press for Resources for the Future, Baltimore, ML, USA.

Majnounian H (1977). Economic evaluation of Khazaneh forest park. University of Tehran Press, Tehran, Iran, pp. 105.

Mankhaus S, Lober DJ (1996). International ecotourism and the valuation of tropical rainforests in Costa Rica. Journal of Environmental Management 47: 1-10. - doi: 10.1006/jema.1996.0031 Mugambi D, Mugendi D, Wambugu A, Mburu J (2006). Estimating recreational benefits of Kakamega forest in Kenya using the travel cost method. In: Proceedings of the Symposium: "Prosperity and Poverty in a Globalised World-Challenges for Agricultural Research". Tropentag, Bonn, Germany.

Offenbach LA, Goodwin BK (1994). A travel-cost analysis of the demand for hunting trips in Kansas. Review of Agricultural Economics 16 (1): 55-61. - doi: 10.2307/1349520

Oladi DJ (2005). An introduction to ecotourism (translation). University of Mazandaran Press, Mazandaran, Iran, pp. 384.

Rosenberger R (1999). The value of ranch open space to tourists. Growth and change 30 (3): 66 73. - doi: 10.1111/j.1468-2257.1999.tb00035.x

Shrestha RK, Stein TV, Clark J (2007). Valuing nature-based recreation in public natural areas of the Apalachicola River region, Florida. Journal of Environmental Management (in press). - doi: 10.1016/j.jenvman.2006.11.014

Willis KG (1991). The recreational value of the forestry commission estate in Great Britain: a Clawson-Snetsch travel cost analysis. Scottish Journal of Political Economy 38 (1): 58-75. - doi: 10.1111/j.1467-9485.1991.tb00301.x

Wood ME (2002). Ecotourism: principles, practices, and policies for sustainability, United Nations Environmental Program, Tour Mirabeau, France and the International ecotourism society, Burlington, VA, USA.

Wunder S (2000). Ecotourism and economic incentives- an empirical approach. Ecological Economics 32: 465-479. - doi: 10.1016/S09218009(99)00119-6

Yachkaschi A (1975). An introduction to the Iranian national and forest parks. University of Tehran Press, Tehran, Iran, pp. 135.

Yachkaschi A (2002). Realization, protection, and rehabilitation of the Iranian environment. JahadE-Keshavarzi Institute of Applied Science Publications, Iran, pp. 444.

Zobeiri M (2000). Forest measurement. University of Tehran Press, Tehran, Iran, pp.401. 